\title{
Validation of Inactivation Methods for Arenaviruses
}

\author{
Silke Olschewski ${ }^{1,+}{ }^{,}$Anke Thielebein ${ }^{1,+}{ }^{+}$, Chris Hoffmann ${ }^{1}$, Olivia Blake ${ }^{1}$, Jonas Müller ${ }^{1}$, Sabrina Bockholt ${ }^{1,2}$, \\ Elisa Pallasch ${ }^{1,2}$, Julia Hinzmann ${ }^{1,2}$, Stephanie Wurr ${ }^{1,2}$, Neele Neddersen ${ }^{1}$, Toni Rieger ${ }^{1}$, Stephan Günther ${ }^{1,2}$ \\ and Lisa Oestereich $1,2, *$ (1)
}

check for updates

Citation: Olschewski, S.; Thielebein, A.; Hoffmann, C.; Blake, O.; Müller, J.; Bockholt, S.; Pallasch, E.; Hinzmann, J.; Wurr, S.; Neddersen, N.; et al. Validation of Inactivation Methods for Arenaviruses. Viruses 2021, 13, 968. https://doi.org/10.3390/v13060968

Academic Editor: Benjamin Brennan

Received: 31 March 2021

Accepted: 20 May 2021

Published: 24 May 2021

Publisher's Note: MDPI stays neutral with regard to jurisdictional claims in published maps and institutional affiliations.

Copyright: (c) 2021 by the authors. Licensee MDPI, Basel, Switzerland. This article is an open access article distributed under the terms and conditions of the Creative Commons Attribution (CC BY) license (https:// creativecommons.org/licenses/by/ $4.0 /)$.
1 Department of Virology, Bernhard-Nocht Institute for Tropical Medicine, 20359 Hamburg, Germany; olschweski@bnitm.de (S.O.); thielebein@bnitm.de (A.T.); hoffmann@bnitm.de (C.H.); olivia.blake@bnitm.de (O.B.); jonas.mueller@bnitm.de (J.M.); bockholt@bnitm.de (S.B.); pallasch@bnitm.de (E.P.); hinzmann@bnitm.de (J.H.); wurr@bnitm.de (S.W.); neddersen@bnitm.de (N.N.); rieger@bnitm.de (T.R.); guenther@bnitm.de (S.G.)

2 German Center for Infectious Research (DZIF), Partner Site Hamburg-Lübeck-Borstel-Riems, 20359 Hamburg, Germany

* Correspondence: oestereich@bnitm.de; Tel.: +49-40-42818-940

+ These authors contributed equally to this work.

\begin{abstract}
Several of the human-pathogenic arenaviruses cause hemorrhagic fever and have to be handled under biosafety level 4 conditions, including Lassa virus. Rapid and safe inactivation of specimens containing these viruses is fundamental to enable downstream processing for diagnostics or research under lower biosafety conditions. We established a protocol to test the efficacy of inactivation methods using the low-pathogenic Morogoro arenavirus as surrogate for the related highly pathogenic viruses. As the validation of chemical inactivation methods in cell culture systems is difficult due to cell toxicity of commonly used chemicals, we employed filter devices to remove the chemical and concentrate the virus after inactivation and before inoculation into cell culture. Viral replication in the cells was monitored over 4 weeks by using indirect immunofluorescence and immunofocus assay. The performance of the protocol was verified using published inactivation methods including chemicals and heat. Ten additional methods to inactivate virus in infected cells or cell culture supernatant were validated and shown to reduce virus titers to undetectable levels. In summary, we provide a robust protocol for the validation of chemical and physical inactivation of arenaviruses in cell culture, which can be readily adapted to different inactivation methods and specimen matrices.
\end{abstract}

Keywords: high-risk pathogens; arenaviruses; inactivation

\section{Introduction}

Pathogenic RNA viruses have repeatedly led to severe outbreaks including the influenza virus pandemic that started in 1918, the human immunodeficiency virus 1 (HIV) global epidemic, the Ebola virus (EBOV) outbreak in 2014, the Zika virus pandemic in 2016 and the current severe acute respiratory syndrome coronavirus type 2 (SARS-CoV-2) pandemic. Zoonotic viruses are responsible for the great majority of the recently emerging infectious diseases. The ongoing SARS-CoV-2 pandemic highlights the importance of fast and sensitive diagnostic methods to enable contact tracing and isolation, to prevent the spread of the disease. Diagnostics and research with high-risk pathogens, however, can be challenging, as pathogen-specific biosafety measures need to be adhered to. A rapid and safe inactivation is very often a basic requirement for many diagnostic and research methods to allow further processing under lower biosafety conditions. The arenaviruses are enveloped segmented single-strand RNA viruses that are distributed worldwide and cause annual zoonotic outbreaks. Several arenaviruses like Machupo virus (MACV), Junín virus (JUNV), Guanarito virus, Sabiá virus, and Lassa virus (LASV) can cause hemorrhagic 
fevers in humans and thus are a serious public health concern. LASV especially has epidemic potential due to the high number of annual cases and the lack of antivirals or a vaccine and is therefore listed in the WHO R\&D Blueprint, which contains a list of potential epidemic threats needing urgent $R \& D$ action [1].

Work with human pathogenic arenaviruses including LASV requires the highest level of biosafety precautions and only a few laboratories worldwide are suitably equipped to conduct such research. Handling samples containing these viruses outside the high biosafety containment requires sample inactivation, which is mostly validated in-house. So far, successful inactivation of arenaviruses with TRIzol, Formalin [2,3], gamma irradiation [4-7], a photoactive compound in combination with UV irradiation [8-10], pH and heat $[6,11]$ have been published. Many other common methods for viral inactivation including acetone or detergents such as Triton X-100 have not been tested. The inactivation efficacy of the frequently used guanidine thiocyanate-containing lysis buffers for RNA purification has only been evaluated for other RNA viruses like EBOV [12,13].

The validation of inactivation methods is difficult as they often include cytotoxic chemicals, which makes it challenging to demonstrate the loss of infectivity of a potential inactivated sample in vitro without causing excessive cytotoxicity. Therefore, we have developed a validation protocol to assess the inactivation efficiency of different chemicals. We used Morogoro virus (MORV), a risk group 2 pathogen closely related to LASV, as a surrogate for the Arenaviridae family. The developed protocol was validated with well-established viral inactivation methods including heat and Formalin. Applying our validation protocol, we evaluated the efficiency of different commonly used inactivation methods. In total, we tested 12 methods, 7 for infected cells and 5 for virus-containing fluids, which allow subsequent RNA isolation, serology analysis, protein analysis using Western blot, immune fluorescence microscopy, histology and flow cytometry.

\section{Materials and Methods}

\subsection{Cells and Virus Stocks}

The amplification of the virus stock, the production of infected cells, and the monitoring of infectivity of potentially inactivated samples was performed in VERO 76 cells (ATCC ${ }^{\circledR}$ CRL-1587 ${ }^{\text {TM }}$, American Type Culture Collection, Manassas, USA). The cells were maintained in medium containing Dulbecco's minimal essential medium (DMEM) supplemented with $3 \%$ fetal calf serum (FCS), $100 \mathrm{U} / \mathrm{mL}$ penicillin, $100 \mu \mathrm{g} / \mathrm{mL}$ streptomycin, $1 \mathrm{mM}$ glutamine, $0.5 \mathrm{mM}$ pyruvate, and $1 \times$ non-essential amino acids (all from Pan Biotech, Aidenbach, Germany) at $37^{\circ} \mathrm{C}$ and $5 \% \mathrm{CO}_{2}$.

MORV strain 3017/2004 had been isolated and sequenced in our laboratory [14] and the used stock was passaged $\leq 3$ times. For the amplification of the stock, cells were infected with a multiplicity of infection (MOI) of 0.01 , the virus-containing supernatant was harvested three days post infection and filtered through a $0.1 \mu \mathrm{m}$ sterile filter unit (Millipore, Burlington, MA, USA). It was further concentrated to $5 \times 10^{6}$ foci forming units (FFU) per $\mathrm{mL}$ via ultrafiltration (see below). The viral titer was determined by immunofocus assay (IFA) as described elsewhere [15-17], and the stock was stored at $-80^{\circ} \mathrm{C}$ until use. This concentrated stock was employed for the validation of the efficacy of the different inactivation methods. For the validation of the efficacy of cellular inactivation methods, cells were infected with a MOI of 0.01 and harvested three days post infection. The supernatant was removed and the cells were trypsinized until detachment, which was monitored visually. The infection rate of the cells was determined by indirect immunofluorescence staining [18] and cells were only used if an infection rate above $50 \%$ was reached. In IFA as well as in indirect immunofluorescence staining, MORV was detected with the Old-World arenavirus NP-specific monoclonal antibody 2LD9 [19].

\subsection{Viral Concentration}

The recovery rate of infectious arenaviruses with the Amicon ${ }^{\circledR}$ Ultra-15 100K Centrifugal Filter Device (Millipore, Burlington, MA, USA) as concentrator was evaluated for 
MORV. Fifty $\mathrm{mL}$ of viral stocks ranging from high to low amounts of infectious particles ( $10^{6}$ to $100 \mathrm{FFU}$ ) were centrifuged through the device at room temperature (RT) until the volume was reduced to $2 \mathrm{~mL}$ in triplicates according to the manufacturer's specifications. The amount of infectious viral particles in the concentrate was analyzed by IFA to determine the recovery rate. Additionally, the amount of viral particles in the input and the flow-through were determined. Viral RNA in input, concentrate, and flow-through was quantified with MORV-specific real-time RT-PCR (see Appendix A).

The filter device was also used for the buffer exchange of the inactivated MORV samples to remove cytotoxic agents. To prevent damage of the filters due to the reagents which would result in higher permeability of the filter, all samples were diluted to reagent concentrations below the manufacturer's specified limits.

\subsection{Inactivation of Infectious Material}

All validation experiments were performed in independent triplicates. The negative controls without virus were treated similarly as the samples, while for the positive controls, all reagents were replaced by equivalent volumes of $1 \times$ PBS, and incubations were performed at RT. For the validation of methods for the inactivation of infected cells, triplicates of $2 \times 10^{7}$ MORV-infected cells (infection rate $>50 \%$ ) were used. As a negative control, $1 \times 10^{6}$ not-infected cells were inactivated and, as a positive control, $2 \times 10^{6}$ MORV-infected cells (infection rate $>50 \%$ ) were used. The validation of methods for the inactivation of infected supernatant was performed with $200 \mu \mathrm{L}$ virus stock, equivalent to $1 \times 10^{6} \mathrm{FFU}$ of MORV. As a negative control, the cell culture supernatant of mock infected cells was used. A summary of the investigated methods is given in Table 1, and the inactivation procedures are described in the following paragraphs.

Table 1. Overview of tested inactivation methods.

\begin{tabular}{|c|c|c|c|}
\hline $\begin{array}{l}\text { Inactivation } \\
\text { Method }\end{array}$ & Purpose & Specimen & $\begin{array}{c}\text { Inactivation } \\
\text { Conditions }\end{array}$ \\
\hline $100 \%$ Acetone & $\begin{array}{l}\text { Immune fluorescence } \\
\text { microscopy }\end{array}$ & Infected cells, without lysis & $\mathrm{RT}, 20 \mathrm{~min}$ \\
\hline 100\% Methanol & $\begin{array}{l}\text { Immune fluorescence } \\
\text { microscopy }\end{array}$ & Infected cells, without lysis & $\mathrm{RT}, 20 \mathrm{~min}$ \\
\hline Acetone/methanol (1:1) & $\begin{array}{l}\text { Immune fluorescence } \\
\text { microscopy }\end{array}$ & Infected cells, without lysis & $\mathrm{RT}, 20 \mathrm{~min}$ \\
\hline $4 \%$ Formaldehyde & $\begin{array}{l}\text { Immune fluorescence } \\
\text { microscopy, histology, } \\
\text { flow cytometry }\end{array}$ & Infected cells, without lysis & $\mathrm{RT}, 30 \mathrm{~min}$ \\
\hline \multirow{8}{*}{$\begin{array}{c}\text { BD Cytofix/Cytoperm }{ }^{\mathrm{TM}} \\
\text { AL buffer + proteinase k } \\
+ \text { ethanol } \\
\text { SDS buffer + heat } \\
\text { AVL buffer + ethanol } \\
1 \% \text { Triton } x-100 \\
\text { SDS buffer + heat } \\
\text { Heat } \\
\text { Serobuvard } \\
\text { filter paper }\end{array}$} & Flow cytometry & Infected cells, without lysis & $\mathrm{RT}, 30 \mathrm{~min}$ \\
\hline & DNA isolation & Infected cells, with lysis & $50^{\circ} \mathrm{C}, 10 \mathrm{~min}$ \\
\hline & Western Blot & Infected cells, with lysis & $95^{\circ} \mathrm{C}, 10 \mathrm{~min}$ \\
\hline & RNA isolation & Cell culture supernatant & $\mathrm{RT}, 10 \mathrm{~min}$ \\
\hline & Serology ${ }^{a}$ & Cell culture supernatant & RT, 30 min \\
\hline & Western Blot & Cell culture supernatant & $95^{\circ} \mathrm{C}, 10 \mathrm{~min}$ \\
\hline & Serology & Cell culture supernatant & $60^{\circ} \mathrm{C}, 60 \mathrm{~min}$ \\
\hline & $\begin{array}{l}\text { Serology } \\
\text { RNA isolation }\end{array}$ & Cell culture supernatant & $\mathrm{RT}, 24 \mathrm{~h}$ \\
\hline
\end{tabular}

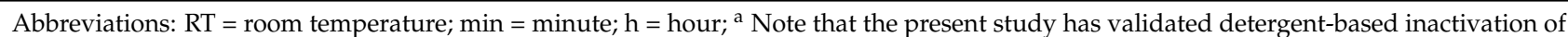
virus only for serum samples pre-diluted at least 1:20 in buffer (serum concentration $<5 \%$ ) before addition of detergent. This concentration corresponds to the FCS concentration in our test matrix (cell culture supernatant). As shown for Ebola virus, high serum concentration may affect inactivation efficacy of detergents [20].

Vero cells were infected with the inactivated samples or controls and cultured in total for 28 days. The cells were visually inspected on a daily basis and split 1:10 once or twice per week depending on their growth rate. The medium of the flasks was kept and added to the new flask in a ratio of 1:2 to maintain the potentially infectious virus in the supernatant. To monitor the infection rate of the cells, samples for immunofluorescence staining and IFA were collected weekly. A detailed scheme of the complete protocol is given in Figure 1. 


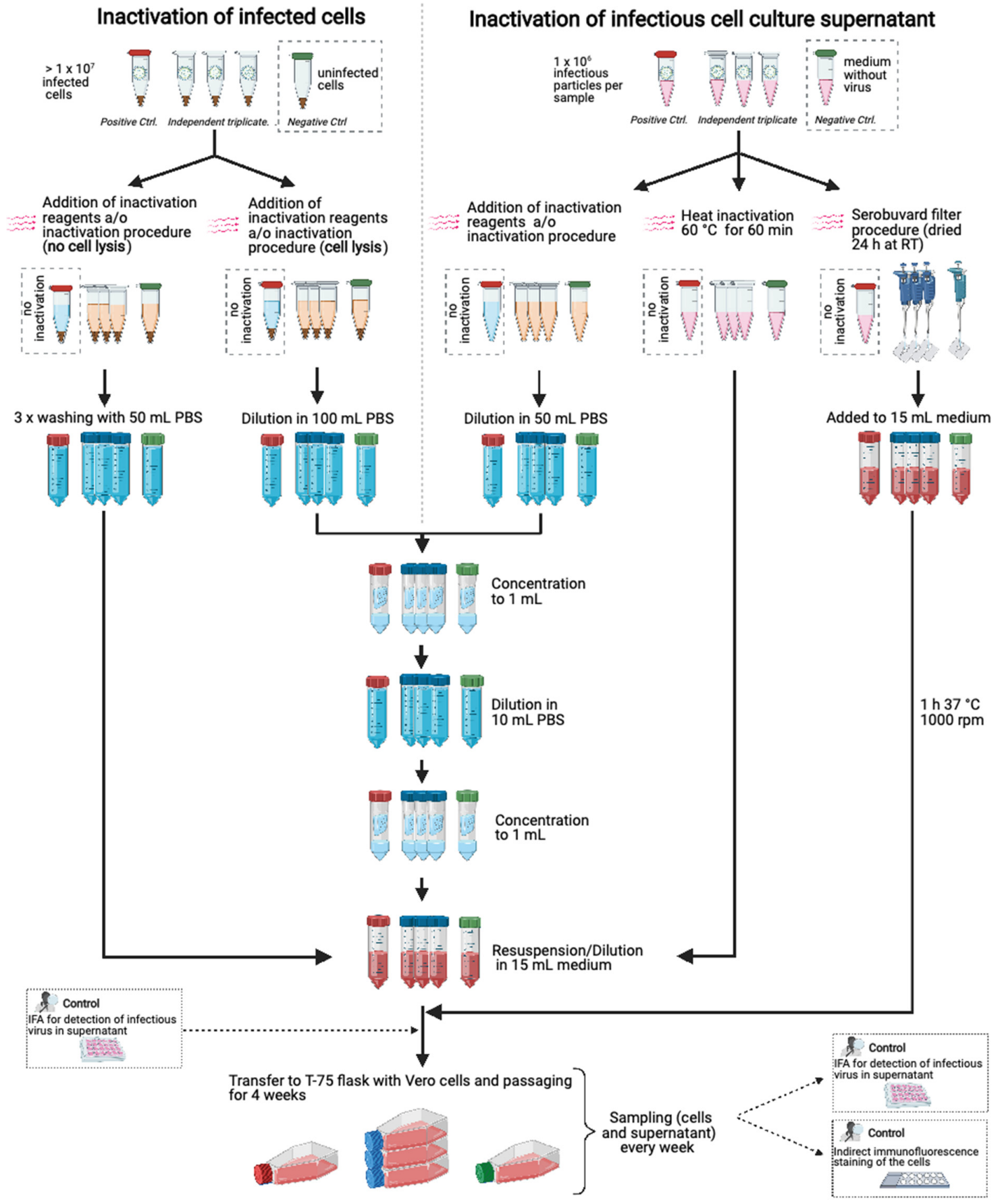

Figure 1. Scheme of the protocol for testing inactivation efficacy in vitro. For the validation of methods to inactivate MORV infected cells, triplicates with $2 \times 10^{7}$ cells, a positive control with $2 \times 10^{6}$ cells (infection rate for both $>50 \%$ ) and $10^{6}$ uninfected cells as a negative control were used. After the inactivation procedure for methods without cell lysis, the cells were washed three times with $50 \mathrm{~mL}$ PBS and resuspended in medium. For methods where cells lysed during the inactivation, samples were diluted in $100 \mathrm{~mL}$ PBS, concentrated to $1 \mathrm{~mL}$, diluted to $10 \mathrm{~mL}$ and concentrated again to $1 \mathrm{~mL}$. For the validation of methods to inactivate MORV-containing cell culture supernatant, $1 \times 10^{6}$ infectious particles were used for the testing approach and the positive control while the negative control contained virus-free medium. After the inactivation procedures, the samples were diluted to $50 \mathrm{~mL}$ in PBS, concentrated to $1 \mathrm{~mL}$, diluted to $10 \mathrm{~mL}$ with PBS and concentrated to $1 \mathrm{~mL}$. The concentrates of the different methods were diluted in medium (15 mL total volume). Heat-inactivated supernatant was diluted in medium directly after incubation, while for the inactivation on Serobuvard paper virus was spotted, dried for $24 \mathrm{~h}$ and added to medium for $1 \mathrm{~h}$ at $37^{\circ} \mathrm{C}$ and $1000 \mathrm{rpm}$. The resuspended cells and diluted samples were used to inoculate pre-seeded cells which were cultured for 4 weeks after infection. The infection rate of cells and supernatant was monitored by indirect immunofluorescence staining and IFA. This figure has been created with BioRender.com. 


\subsubsection{Tested Inactivation Methods for Infected Cells without Cell Lysis}

The infected cells were pelleted by centrifugation for $5 \mathrm{~min}$ at $500 \times g$ and subsequently resuspended in $2 \mathrm{~mL}$ acetone (100\%), acetone/methanol (1:1), methanol (100\%), $4 \%$ formaldehyde in 1× PBS (all Carl Roth, Karlsruhe, Germany), or BD Cytofix/Cytoperm ${ }^{\mathrm{TM}}$ buffer (BD BioScience; San Jose, USA). The cells were incubated for $20 \mathrm{~min}$ (acetone, acetone/methanol, methanol) or $30 \mathrm{~min}$ ( $4 \%$ formaldehyde, BD Cytofix/Cytoperm ${ }^{\mathrm{TM}}$ ) at RT. Afterwards, the cells were washed three times with $50 \mathrm{~mL} 1 \times$ PBS and pelleted at $300 \times g$ for $5 \mathrm{~min}$. The cells were resuspended in $15 \mathrm{~mL}$ medium and used to infect pre-seeded cells.

\subsubsection{Tested Inactivation Methods for Infected Cells with Cell Lysis}

To test the inactivation with Buffer AL from the DNeasy Blood and Tissue kit (Qiagen, Hilden, Germany), the infected cells were pelleted (centrifugation for $5 \mathrm{~min}$ at $500 \times g)$ and resuspended in $0.8 \mathrm{~mL} 1 \times$ PBS. $80 \mu \mathrm{L}$ proteinase $\mathrm{K}$ and $0.8 \mathrm{~mL}$ buffer AL were added followed by incubation at $56^{\circ} \mathrm{C}$ for $10 \mathrm{~min}$ (procedure according to manual). For the testing of SDS sample buffer (containing $6 \%$ natriumlaurylsulfat (SDS), $150 \mathrm{mM}$ tris(hydroxymethyl)aminomethane $\mathrm{pH}$ 6.8, 30\% glycerol, $100 \mathrm{mM}$ dithiothreitol, bromphenolblue), the pelleted cells were resuspended in $1 \mathrm{~mL} 1 \times$ PBS, mixed with $0.5 \mathrm{~mL}$ SDS sample buffer, and heated for $10 \mathrm{~min}$ at $95^{\circ} \mathrm{C}$ on a heat block.

The inactivated samples from the two methods were afterwards diluted to $100 \mathrm{~mL}$ in $1 \times$ PBS to reduce the concentration of chemicals in the samples below the manufacturer's specified limits of the Amicon ${ }^{\circledR}$ Ultra-15 100K Centrifugal Filter Device. They were concentrated to $1 \mathrm{~mL}$ by centrifugation with up to $2500 \times \mathrm{g}$ for 2 to $10 \mathrm{~min}$. The concentrate was again diluted in $10 \mathrm{~mL} 1 \times \mathrm{PBS}$ and concentrated to $1 \mathrm{~mL}$. This concentrate was diluted in medium to a total volume of $15 \mathrm{~mL}$ and used to infect pre-seeded cells.

\subsubsection{Tested Inactivation Methods for Infectious MORV in Cell Culture Supernatant AVL Buffer, Triton X-100 and SDS Buffer}

Note that $800 \mu \mathrm{L}$ of buffer AVL from the QIAamp Viral RNA Mini Kit (Qiagen, Hilden, Germany) were mixed with $200 \mu \mathrm{L}$ of MORV stock and incubated for $10 \mathrm{~min}$ at RT. Afterwards, $800 \mu \mathrm{L}$ of $>99 \%$ ethanol (Carl Roth, Karlsruhe, Germany) were added to the AVL-virus mixture.

$200 \mu \mathrm{L}$ of a solution of $2 \%$ Triton X-100 in $1 \times$ PBS (Carl Roth, Karlsruhe, Germany) were mixed with $200 \mu \mathrm{L}$ of MORV stock and incubated for $30 \mathrm{~min}$ at RT.

$100 \mu \mathrm{L}$ of SDS sample buffer (see above) were mixed with $200 \mu \mathrm{L}$ of MORV stock and incubated for $10 \mathrm{~min}$ at $95^{\circ} \mathrm{C}$ on a heat block

The inactivated samples were diluted to $50 \mathrm{~mL}$ in $1 \times$ PBS to reduce the concentration of chemicals in the samples below the manufacturer's specified limits of the Amicon ${ }^{\circledR}$ Ultra$15100 \mathrm{~K}$ Centrifugal Filter Device. They were concentrated to $1 \mathrm{~mL}$ by centrifugation with up to $2500 \times \mathrm{g}$ for 2 to $10 \mathrm{~min}$. The concentrate was again diluted in $10 \mathrm{~mL} 1 \times \mathrm{PBS}$ and concentrated to $1 \mathrm{~mL}$. This concentrate was diluted in medium to a total volume of $15 \mathrm{~mL}$ and used to infect pre-seeded cells.

Heat Inactivation

For heat inactivation, $200 \mu \mathrm{L}$ of the MORV stock was incubated for $60 \mathrm{~min}$ at $60^{\circ} \mathrm{C}$ on a heat block. It was afterwards diluted in $15 \mathrm{~mL}$ medium and used to infect pre-seeded cells.

\section{Serobuvard Filter Paper}

For the inactivation of MORV on Serobuvard filter paper (Serobuvard, LDA 22, Zoopole, France), $200 \mu \mathrm{L}$ of MORV stock were spotted on a small piece of filter paper and dried for $24 \mathrm{~h}$ and RT. The dried spot was placed into a conical centrifuge tube, and $15 \mathrm{~mL}$ of medium were added. The tube was agitated for $1 \mathrm{~h}$ at $37^{\circ} \mathrm{C}$ and $1000 \mathrm{rpm}$. The medium was used to infect pre-seeded cells. 


\section{Results}

\subsection{Verification of Ultrafiltration to Concentrate Arenaviruses}

The use of the Amicon ${ }^{\circledR}$ Ultra-15 Centrifugal Filter Device as concentrator has been described for a large variety of viruses and just recently also for arenaviruses such as JUNV, MACV, LASV and Tacaribe virus (TCRV) [21,22]. However, the recovery rate of these devices when used for concentrating arenaviruses has not yet been determined, and published recovery rates of infectious particles vary between $90 \%$ and $100 \%$ [23] for retroviruses to only $15 \%$ for SARS-CoV-2 [24]. Therefore, we first determined the recovery rate of infectious virus from cell culture supernatant for the arenavirus MORV.

To assess the impact of the virus concentration in the starting material on the recovery rate, we performed ultrafiltration with different input amounts of MORV. The numbers of infectious particles ranged from $10^{6}$ to $100 \mathrm{FFU}$, and the experiments were done in triplicates. The mean recovery rate of infectious MORV was found to be $56-106 \%$, and the recovery rate of the viral RNA ranged from 49 to 117\% (Figure 2). Lower recovery rates were generally observed for the lower input amounts. However, we still achieved more than $50 \%$ mean recovery at the lowest tested input (100 FFU). Therefore, ultrafiltration with this device is well suited to concentrate arenaviruses and was used in this study to remove cytotoxic substances after inactivation.
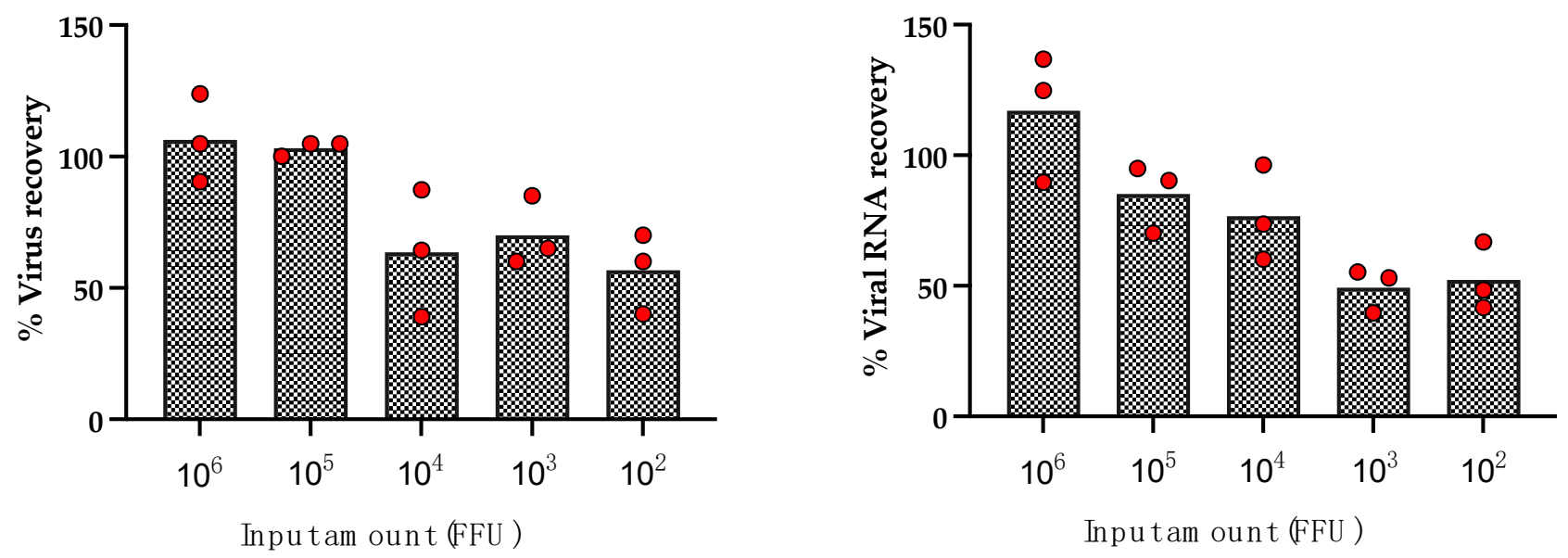

Total amount of infectious virus particles (FFU)

Total amount of viral RNA (copies)

\begin{tabular}{|c|c|c|c|c|c|}
\hline $\begin{array}{l}\text { Input } \\
(50 \mathrm{~mL})\end{array}$ & $\begin{array}{l}\text { Concentrate } \\
(2 \mathrm{~mL})\end{array}$ & $\begin{array}{l}\text { Flow-through } \\
(48 \mathrm{~mL})\end{array}$ & $\begin{array}{l}\text { Input } \\
(50 \mathrm{~mL})\end{array}$ & $\begin{array}{l}\text { Concentrate } \\
(2 \mathrm{~mL})\end{array}$ & $\begin{array}{l}\text { Flow-through } \\
(48 \mathrm{~mL})\end{array}$ \\
\hline $1.1 \times 10^{6}$ & $1.1 \times 10^{6}\left( \pm 1.7 \times 10^{5}\right)$ & $5.5 \times 10^{3}\left( \pm 4.3 \times 10^{3}\right)$ & $1.1 \times 10^{9}$ & $1.3 \times 10^{9}\left( \pm 2.6 \times 10^{8}\right)$ & $9.4 \times 10^{5}\left( \pm 6.6 \times 10^{5}\right)$ \\
\hline $1.1 \times 10^{5}$ & $1.1 \times 10^{5}\left( \pm 2.9 \times 10^{3}\right)$ & $\left.6.4 \times 10^{2} \pm 5.0 \times 10^{2}\right)$ & $4.8 \times 10^{7}$ & $4.1 \times 10^{7}\left( \pm 6.3 \times 10^{6}\right)$ & $1.5 \times 10^{5}\left( \pm 3.7 \times 10^{4}\right)$ \\
\hline $1.1 \times 10^{4}$ & $3.9 \times 10^{3}\left( \pm 2.6 \times 10^{3}\right)$ & $<250$ & $3.3 \times 10^{6}$ & $\left.2.6 \times 10^{6} \pm 6.0 \times 10^{5}\right)$ & $3.9 \times 10^{3}\left( \pm 5.6 \times 10^{2}\right)$ \\
\hline $1.0 \times 10^{3}$ & $7.0 \times 10^{2}\left( \pm 1.3 \times 10^{2}\right)$ & $<250$ & $4.1 \times 10^{5}$ & $2.0 \times 10^{5}\left( \pm 3.4 \times 10^{4}\right)$ & $8.4 \times 10^{3}\left( \pm 6.2 \times 10^{3}\right)$ \\
\hline $1.0 \times 10^{2}$ & $5.7 \times 10^{1}\left( \pm 1.5 \times 10^{1}\right)$ & $<250$ & $1.4 \times 10^{4}$ & $7.3 \times 10^{3}\left( \pm 1.8 \times 10^{3}\right)$ & $<5 \times 10^{2}$ \\
\hline
\end{tabular}

Figure 2. Viral recovery rates after concentration of MORV with Amicon ${ }^{\circledR}$ Ultra-15 Centrifugal Filter Devices depending on the input concentrations. Different amounts of MORV virus stock ranging from $10^{6} \mathrm{FFU}$ to $100 \mathrm{FFU}$ were diluted in $50 \mathrm{~mL}$ and concentrated to $2 \mathrm{~mL}$ using Amicon ${ }^{\circledR}$ Ultra-15 Centrifugal Filter Devices in triplicates for each input concentration. The amounts of infectious viral particles in the input $(50 \mathrm{~mL})$, concentrate $(2 \mathrm{~mL})$, and flow-through $(48 \mathrm{~mL})$ were determined with IFA and used to calculate the recovery rate. Recovery rates of viral RNA were determined with MORV-specific real-time RT-PCR. The recovery rates in the concentrate for each experiment are depicted as red circles and the bars represent the mean. The amounts of infectious viral particles as well as viral RNA amount for the input, the concentrate and the flow-through are shown in the table. Values are given as mean with standard deviation. 


\subsection{Evaluation of the Efficacy of Tested Inactivation Methods}

We first tested our developed inactivation validation protocol with the published methods of inactivation using $4 \%$ formaldehyde and heat as a proof-of-concept experiment. We could replicate the previously published results of complete inactivation of infectious particles with both methods. Next, we validated the other 10 methods and successfully demonstrated complete inactivation for each method. We could not detect infectious MORV by immunofluorescence staining or IFA within 4 weeks post-inoculation in any of the negative controls or the inactivated triplicates. Infectious MORV was, however, detected at all investigated time points in the positive controls with both control assays. Therefore, we could show that all tested methods lead to a complete virus inactivation. A summary of the results is given in Table 2.

Table 2. Overview of the efficacy of the tested inactivation methods.

\begin{tabular}{|c|c|c|c|}
\hline $\begin{array}{l}\text { Inactivation } \\
\text { Method }\end{array}$ & Sample Type & $\begin{array}{c}\text { Quantity of Infectious } \\
\text { Material }\end{array}$ & Result (Successful/Total) \\
\hline $100 \%$ Acetone & Infected cells & $\begin{array}{l}>10^{7} \text { cells } \\
\text { infected cells }\end{array}$ & Complete inactivation $(3 / 3)$ \\
\hline 100\% Methanol & Infected cells & $\begin{array}{l}>10^{7} \text { cells } \\
\text { infected cells }\end{array}$ & Complete inactivation $(3 / 3)$ \\
\hline Acetone/methanol (1:1) & Infected cells & $\begin{array}{l}>10^{7} \text { cells } \\
\text { infected cells }\end{array}$ & Complete inactivation $(3 / 3)$ \\
\hline $4 \%$ Formaldehyde & Infected cells & $\begin{array}{c}>10^{7} \text { cells } \\
\text { infected cells }\end{array}$ & Complete inactivation $(3 / 3)$ \\
\hline BD Cytofix/Cytoperm ${ }^{\mathrm{TM}}$ & Infected cells & $\begin{array}{c}>10^{7} \text { cells } \\
\text { infected cells }\end{array}$ & Complete inactivation $(3 / 3)$ \\
\hline $\begin{array}{c}\text { AL buffer + proteinase } \mathrm{k} \\
+ \text { ethanol }\end{array}$ & Infected cells & $\begin{array}{l}>10^{7} \text { cells } \\
\text { infected cells }\end{array}$ & Complete inactivation $(3 / 3)$ \\
\hline SDS buffer + heat & Infected cells & $\begin{array}{l}>10^{7} \text { cells } \\
\text { infected cells }\end{array}$ & Complete inactivation $(3 / 3)$ \\
\hline AVL buffer + ethanol & $\begin{array}{l}\text { Cell culture } \\
\text { supernatant }\end{array}$ & $10^{6} \mathrm{FFU}$ & Complete inactivation $(3 / 3)$ \\
\hline $1 \%$ Triton $x-100$ & $\begin{array}{l}\text { Cell culture } \\
\text { supernatant }\end{array}$ & $10^{6} \mathrm{FFU}$ & Complete inactivation $(3 / 3)$ \\
\hline SDS buffer + heat & $\begin{array}{l}\text { Cell culture } \\
\text { supernatant }\end{array}$ & $10^{6} \mathrm{FFU}$ & Complete inactivation $(3 / 3)$ \\
\hline Heat & $\begin{array}{l}\text { Cell culture } \\
\text { supernatant }\end{array}$ & $10^{6} \mathrm{FFU}$ & Complete inactivation $(3 / 3)$ \\
\hline $\begin{array}{l}\text { Serobuvard } \\
\text { filter paper }\end{array}$ & $\begin{array}{l}\text { Cell culture } \\
\text { supernatant }\end{array}$ & $10^{6} \mathrm{FFU}$ & Complete inactivation $(3 / 3)$ \\
\hline
\end{tabular}

\section{Discussion}

Diagnostics and research of high-risk pathogens in lower biosafety environments depends on the availability of safe and efficacious inactivation methods. While numerous comprehensive inactivation studies have been published for some high-risk viruses such as EBOV [12,13,25-27], this has so far been lacking for the Arenaviridae family. As a result, working with arenaviruses often requires a time-consuming in-house validation process of inactivation methods. One aim was to develop an in vitro protocol that allows researchers to assess the inactivation efficacy of different commonly available reagents and treatments for non-toxic as well as for cytotoxic reagents. Before samples inactivated with cytotoxic reagents come into contact with cells, the respective substances must be reduced or removed either by dilution and subsequent concentration or by buffer exchange. Buffer exchange, for example by dialysis, leads to a significantly increased incubation time in the inactivating agents, which can, by itself, reduce the number of infectious viruses and may falsify the results. Hence, we used Amicon ${ }^{\circledR}$ Ultra-15 100K Centrifugal Filter Devices to concentrate arenaviruses via ultrafiltration and to remove cytotoxic substances. 
We observed a high mean recovery rate of infectious MORV particles of 56-106\%, which is close to the recovery rate for retroviruses [23]. The recovery rate of infectious MORV particles as well as the recovery rate of viral RNA showed a dependency on the amount of virus. However, even inputs as low as 100 FFU showed a mean recovery rate above $50 \%$. Therefore, ultrafiltration represents a suitable tool to generate high-titer arenaviral stocks or to study samples with low virus concentrations, as in the case of waste-water studies. In contrast to other studies $[13,28,29]$, we had a low volume of the inactivated samples after the concentration preventing dilution effects, which allowed us to inoculate the complete inactivated sample on one T-75 flask of cells. We also chose a very long passaging time of four weeks. Both measures ensured that even the smallest amount of possibly non-inactivated virus could amplify.

With this study, we provide a protocol to assess the efficacy of a broad range of inactivation methods for the most widely used specimens in laboratory research (cell culture supernatant and infected cells). Using our protocol, we validated a broad range of inactivation methods for viruses of the Arenaviridae family. We could confirm the previously shown complete inactivation with heat and with $4 \%$ formaldehyde. Furthermore, we validated other commonly used inactivation methods including AVL, 1\% Triton X-100, SDS-buffer, Serobuvard filter paper, acetone, methanol, AL buffer and BD Cytofix/Cytoperm ${ }^{\mathrm{TM}}$. All 10 additional tested inactivation methods completely inactivated the infectious cell culture supernatant and infected cells and thus allow the downstream processing in numerous applications such as flow cytometry, serology, or RNA isolation in laboratories with lower biosafety level. Our study focused on the inactivation of infected cells and cell culture supernatant and the inactivation efficacy may vary for other specimens such as serum, plasma, stool, saliva, or tissue. For EBOV, it has already been shown that detergent-based inactivation was less efficient in serum compared to cell-culture medium [20]. Therefore, inactivation experiments may have to be repeated using downstream application-specific matrices. We expect that our protocol can be easily adapted to other matrices and used for the validation of further inactivation methods.

Author Contributions: Conceptualization and methodology, T.R., S.G. and L.O.; validation, S.O. and E.P., investigation, S.O., A.T., C.H., O.B., J.M., S.B., E.P., J.H., S.W. and N.N.; data curation, L.O.; writing-original draft preparation, S.O., A.T. and L.O.; writing—review and editing, S.O., A.T., L.O. and S.G.; visualization, S.O. and A.T.; All authors have read and agreed to the published version of the manuscript.

Funding: This project has received funding from the European Union's Horizon 2020 research and innovation program under grant agreement No. 653316 (European Virus Archive goes global) and 871029 (European Virus Archive GLOBAL) awarded to S.G. L.O. received funding from the Leibniz Association (grant number J59/2018). S.O. was supported by the Jürgen Manchot foundation Ph.D. fellowship.

Institutional Review Board Statement: Not applicable.

Informed Consent Statement: Not applicable.

Data Availability Statement: Not applicable.

Acknowledgments: We want to thank Petra Emmerich, Serio Gomez, Beatriz Escudero-Perez and Emily Nelson for the helpful discussions. Further, we thank Saskia Johanns for her help with the MORV concentration tests.

Conflicts of Interest: The authors declare no conflict of interest. The funders had no role in the design of the study; in the collection, analyses, or interpretation of data; in the writing of the manuscript, or in the decision to publish the results.

\section{Appendix A. Quantification of Viral RNA}

Viral RNA levels were analyzed using real-time RT-PCR. RNA extraction was performed using the QIAamp Viral RNA Mini Kit following the manufacturer's instructions (QIAGEN, Venlo, Netherlands). The SuperScript ${ }^{\mathrm{TM}}$ III Platinum ${ }^{\mathrm{TM}}$ One-Step qRT-PCR Kit 
(Thermo Fisher Scientific, Waltham, USA) was used for the PCR reactions, which were set up based on the protocol described in Nikisins et al. 2015 [30]. The primer pair and probe were modified based on the MORV L protein sequence (Table A1). Primers and probe were produced by Integrated DNA Technologies, Inc. In vitro transcripts based on the MORV L protein sequence have also been used to create a standard curve. The details for the cycling conditions are given in Tables A2 and A3.

Table A1. PCR primer and probe sequences.

\begin{tabular}{cc}
\hline Primer/Probe $^{\mathbf{1}}$ & Sequence $\left(\mathbf{5}^{\prime} \rightarrow \mathbf{3}^{\prime}\right)$ \\
\hline Nikisins F2 MORV & AAT CAA TTT GTG AAT GTG CCA \\
Nikisins R MORV & GCT CAG GTT TCA TAT AGT TTA GAC CA \\
Nikisins TM MORV & /56-FAM / AAG TGG GGC /ZEN/CCA ATG \\
& ATG TCC CCA TT /3' IBFQ / \\
\hline${ }^{1}$ Probes $=250 \mathrm{~nm}$ PrimeTime ${ }^{\circledR} 5^{\prime}$ 6-FAM ${ }^{\mathrm{TM}} / \mathrm{ZEN}^{\mathrm{TM}} / \mathbf{3}^{\prime}$ IBFQ.
\end{tabular}

Table A2. Master mix set-up for the qRT-PCR.

\begin{tabular}{ccc}
\hline Reagent & Concentration per Reaction & Volume per Reaction $[\mu \mathrm{L}]$ \\
\hline SuperScript $^{\mathrm{TM}}$ III Reverse & & \\
Transcriptase/Platinum ${ }^{\mathrm{TM}}$ & $0.5 \mu \mathrm{L}$ & 0.5 \\
Taq DNA Polymerase Mix & $1 \times$ & \\
Superscript mix $[2 \times]$ & $0.2 \mu \mathrm{M}$ & 12.5 \\
Probe $[10 \mu \mathrm{M}]$ & $0.5 \mu \mathrm{M}$ & 0.5 \\
Forward Primer $[10 \mu \mathrm{M}]$ & $0.52 \mu \mathrm{M}$ & 1.25 \\
Reverse Primer $[10 \mu \mathrm{M}]$ & & 1.3 \\
Nuclease-free $\mathrm{H}_{2} \mathrm{O}$ & & 3.95 \\
Template & & 5 \\
\hline Total volume & 25 \\
\hline
\end{tabular}

Table A3. Cycling parameters for qRT-PCRs with the Platinum ${ }^{\mathrm{TM}}$ Taq DNA Polymerase Mix.

\begin{tabular}{ccc}
\hline Step & Temperature $\left[{ }^{\circ} \mathbf{C}\right]$ & Time \\
\hline RT-step & 55 & $20 \mathrm{~min}$ \\
Polymerase Activation & 95 & $2 \mathrm{~min}$ \\
\hline & 95 & $15 \mathrm{~s}$ \\
Cycling $(45 \times)$ & 55 & $45 \mathrm{~s}$ \\
& 72 & $15 \mathrm{~s}$ \\
\hline
\end{tabular}

\section{References}

1. Mehand, M.S.; Al-Shorbaji, F.; Millett, P.; Murgue, B. The WHO R\&D Blueprint: 2018 review of emerging infectious diseases requiring urgent research and development efforts. Antivir. Res. 2018, 159, 63-67. [CrossRef]

2. Retterer, C.; Kenny, T.; Zamani, R.; Altamura, L.A.; Kearney, B.; Jaissle, J.; Coyne, S.; Olschner, S.; Harbourt, D. Strategies for Validation of Inactivation of Viruses with Trizol ${ }^{\circledR}$ LS and Formalin Solutions. Appl. Biosaf. 2020, 25, 74-82. [CrossRef]

3. Kochel, T.; Kocher, G.; Ksiazek, T.; Burans, J. Evaluation of TRIzol LS Inactivation of Viruses. Appl. Biosaf. 2017, 22, 52-55. [CrossRef]

4. Feldmann, F.; Shupert, W.L.; Haddock, E.; Twardoski, B.; Feldmann, H. Gamma Irradiation as an Effective Method for Inactivation of Emerging Viral Pathogens. Am. J. Trop. Med. Hyg. 2019, 100, 1275-1277. [CrossRef]

5. Elliott, L.H.; McCormick, J.B.; Johnson, K.M. Inactivation of Lassa, Marburg, and Ebola viruses by gamma irradiation. J. Clin. Microbiol. 1982, 16, 704-708. [CrossRef] [PubMed]

6. Mitchell, S.W.; McCormick, J.B. Physicochemical inactivation of Lassa, Ebola, and Marburg viruses and effect on clinical laboratory analyses. J. Clin. Microbiol. 1984, 20, 486-489. [CrossRef] [PubMed]

7. Eberlein, K.; Hintereder, G.; Schilling, S.; Rodel, C.; Juling-Pohlit, L. Change in blood test after irradiation with high doses for inactivation of Lassa virus. Eur. J. Clin. Microbiol. Infect. Dis. 2009, 28, 1155-1157. [CrossRef] 
8. Schneider, K.; Wronka-Edwards, L.; Leggett-Embrey, M.; Walker, E.; Sun, P.; Ondov, B.; Wyman, T.H.; Rosovitz, M.J.; Bohn, S.S.; Burans, J.; et al. Psoralen Inactivation of Viruses: A Process for the Safe Manipulation of Viral Antigen and Nucleic Acid. Viruses 2015, 7, 5875-5888. [CrossRef] [PubMed]

9. Hanson, C.V. Photochemical inactivation of deoxyribonucleic and ribonucleic acid viruses by chlorpromazine. Antimicrob. Agents Chemother. 1979, 15, 461-464. [CrossRef]

10. Lanteri, M.C.; Santa-Maria, F.; Laughhunn, A.; Girard, Y.A.; Picard-Maureau, M.; Payrat, J.M.; Irsch, J.; Stassinopoulos, A.; Bringmann, P. Inactivation of a broad spectrum of viruses and parasites by photochemical treatment of plasma and platelets using amotosalen and ultraviolet A light. Transfusion 2020, 60, 1319-1331. [CrossRef]

11. Allison, L.; Salter, M.; Mann, G.; Howard, C.R. Thermal inactivation of Pichinde virus. J. Virol. Methods 1985, 11, 259-264. [CrossRef]

12. Smither, S.J.; Weller, S.A.; Phelps, A.; Eastaugh, L.; Ngugi, S.; O’Brien, L.M.; Steward, J.; Lonsdale, S.G.; Lever, M.S. Buffer AVL Alone Does Not Inactivate Ebola Virus in a Representative Clinical Sample Type. J. Clin. Microbiol. 2015, 53, 3148-3154. [CrossRef]

13. Alfson, K.J.; Griffiths, A. Development and Testing of a Method for Validating Chemical Inactivation of Ebola Virus. Viruses 2018, 10, 126. [CrossRef]

14. Gunther, S.; Hoofd, G.; Charrel, R.; Roser, C.; Becker-Ziaja, B.; Lloyd, G.; Sabuni, C.; Verhagen, R.; van der Groen, G.; Kennis, J.; et al. Mopeia virus-related arenavirus in natal multimammate mice, Morogoro, Tanzania. Emerg. Infect. Dis. 2009, 15, $2008-2012$. [CrossRef] [PubMed]

15. Asper, M.; Sternsdorf, T.; Hass, M.; Drosten, C.; Rhode, A.; Schmitz, H.; Gunther, S. Inhibition of different Lassa virus strains by alpha and gamma interferons and comparison with a less pathogenic arenavirus. J. Virol. 2004, 78, 3162-3169. [CrossRef]

16. Gunther, S.; Asper, M.; Roser, C.; Luna, L.K.; Drosten, C.; Becker-Ziaja, B.; Borowski, P.; Chen, H.M.; Hosmane, R.S. Application of real-time PCR for testing antiviral compounds against Lassa virus, SARS coronavirus and Ebola virus in vitro. Antivir. Res. 2004, 63, 209-215. [CrossRef] [PubMed]

17. Rieger, T.; Merkler, D.; Gunther, S. Infection of type I interferon receptor-deficient mice with various old world arenaviruses: A model for studying virulence and host species barriers. PLoS ONE 2013, 8, e72290. [CrossRef] [PubMed]

18. Gunther, S.; Emmerich, P.; Laue, T.; Kuhle, O.; Asper, M.; Jung, A.; Grewing, T.; ter Meulen, J.; Schmitz, H. Imported lassa fever in Germany: Molecular characterization of a new lassa virus strain. Emerg. Infect. Dis. 2000, 6, 466-476. [CrossRef]

19. Hufert, F.T.; Ludke, W.; Schmitz, H. Epitope mapping of the Lassa virus nucleoprotein using monoclonal anti-nucleocapsid antibodies. Arch. Virol. 1989, 106, 201-212. [CrossRef] [PubMed]

20. van Kampen, J.J.A.; Tintu, A.; Russcher, H.; Fraaij, P.L.A.; Reusken, C.; Rijken, M.; van Hellemond, J.J.; van Genderen, P.J.J.; Koelewijn, R.; de Jong, M.D.; et al. Ebola Virus Inactivation by Detergents Is Annulled in Serum. J. Infect. Dis. 2017, 216, 859-866. [CrossRef]

21. Gowen, B.B.; Wong, M.H.; Larson, D.; Ye, W.; Jung, K.H.; Sefing, E.J.; Skirpstunas, R.; Smee, D.F.; Morrey, J.D.; Schneller, S.W. Development of a new tacaribe arenavirus infection model and its use to explore antiviral activity of a novel aristeromycin analog. PLoS ONE 2010, 5, e12760. [CrossRef]

22. Huang, C.; Kolokoltsova, O.A.; Mateer, E.J.; Koma, T.; Paessler, S. Highly Pathogenic New World Arenavirus Infection Activates the Pattern Recognition Receptor Protein Kinase R without Attenuating Virus Replication in Human Cells. J. Virol. $2017,91$. [CrossRef]

23. Saha, K.; Lin, Y.C.; Wong, P.K.Y. A simple method for obtaining highly viable virus from culture supernatant. J. Virol. Methods 1994, 46, 349-352. [CrossRef]

24. Welch, S.R.; Davies, K.A.; Buczkowski, H.; Hettiarachchi, N.; Green, N.; Arnold, U.; Jones, M.; Hannah, M.J.; Evans, R.; Burton, C.; et al. Analysis of Inactivation of SARS-CoV-2 by Specimen Transport Media, Nucleic Acid Extraction Reagents, Detergents, and Fixatives. J. Clin. Microbiol. 2020, 58. [CrossRef] [PubMed]

25. Chepurnov, A.A.; Bakulina, L.F.; Dadaeva, A.A.; Ustinova, E.N.; Chepurnova, T.S.; Baker, J.R., Jr. Inactivation of Ebola virus with a surfactant nanoemulsion. Acta Trop. 2003, 87, 315-320. [CrossRef]

26. Haddock, E.; Feldmann, F.; Feldmann, H. Effective Chemical Inactivation of Ebola Virus. Emerg. Infect. Dis. 2016, 22, 1292-1294. [CrossRef]

27. Dietscher, C.; Winter, U.; Pelikan, J.M. The Application of Salutogenesis in Hospitals. In The Handbook of Salutogenesis; Mittelmark, M.B., Sagy, S., Eriksson, M., Bauer, G.F., Pelikan, J.M., Lindstrom, B., Espnes, G.A., Eds.; Springer: Cham, Switzerland, 2017; pp. 277-298.

28. Blow, J.A.; Dohm, D.J.; Negley, D.L.; Mores, C.N. Virus inactivation by nucleic acid extraction reagents. J. Virol. Methods 2004, 119, 195-198. [CrossRef] [PubMed]

29. Roberts, P.L. Virus inactivation by solvent/detergent treatment using Triton X-100 in a high purity factor VIII. Biologicals 2008, 36, 330-335. [CrossRef] [PubMed]

30. Nikisins, S.; Rieger, T.; Patel, P.; Muller, R.; Gunther, S.; Niedrig, M. International external quality assessment study for molecular detection of Lassa virus. PLoS Negl. Trop. Dis. 2015, 9, e0003793. [CrossRef] [PubMed] 